Article

\title{
Synthesis of New Cytotoxic Aminoanthraquinone Derivatives via Nucleophilic Substitution Reactions
}

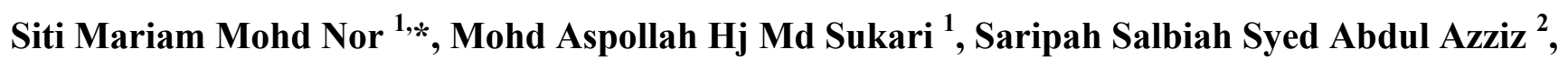
Wong Chee Fah ${ }^{3}$, Hasimah Alimon ${ }^{3}$ and Siti Fadilah Juhan ${ }^{1}$

1 Department of Chemistry, Faculty of Science, Universiti Putra Malaysia, 43400 UPM Serdang, Selangor, Malaysia

2 Department of Chemistry, Faculty of Science and Mathematics, Universiti Pendidikan Sultan Idris, 35900 Tanjong Malim, Perak, Malaysia

3 Department of Biology, Faculty of Science and Mathematics, Universiti Pendidikan Sultan Idris, 35900 Tanjong Malim, Perak, Malaysia

* Author to whom correspondence should be addressed; E-Mail: smariam@upm.edu.my; Tel.: +603-8946-6780; Fax: +603-8943-5380.

Received: 14 May 2013; in revised form: 21 June 2013 / Accepted: 25 June 2013 /

Published: 8 July 2013

Abstract: Aminoanthraquinones were successfully synthesized via two reaction steps. 1,4-Dihydroxyanthraquinone (1) was first subjected to methylation, reduction and acylation to give an excellent yield of anthracene-1,4-dione (3), 1,4-dimethoxyanthracene9,10-dione (5) and 9,10-dioxo-9,10-dihydroanthracene-1,4-diyl diacetate (7). Treatment of 1, 3, 5 and 7 with $\mathrm{BuNH}_{2}$ in the presence of $\mathrm{PhI}(\mathrm{OAc})_{2}$ as catalyst produced seven aminoanthraquinone derivatives 1a, b, 3a, and 5a-d. Amination of $\mathbf{3}$ and $\mathbf{5}$ afforded three new aminoanthraquinones, namely 2-(butylamino)anthracene-1,4-dione (3a), 2-(butylamino)anthracene-9,10-dione (5a) and 2,3-(dibutylamino)anthracene-9,10-dione (5b). All newly synthesised aminoanthraquinones were examined for their cytotoxic activity against MCF-7 (estrogen receptor positive human breast) and Hep-G2 (human hepatocellular liver carcinoma) cancer cells using MTT assay. Aminoanthraquinones 3a, 5a and $\mathbf{5 b}$ exhibited strong cytotoxicity towards both cancer cell lines $\left(\mathrm{IC}_{50} 1.1-13.0 \mu \mathrm{g} / \mathrm{mL}\right)$.

Keywords: methylation; reduction; acylation; amination; substitution; aminoanthraquinone; mechanism; cytotoxic; MCF-7; Hep-G2 


\section{Introduction}

Natural and synthetic anthraquinones have attracted the interest of researchers due to their significant biological activities such as antitumour [1-4], anti-inflammatory [5], antimalarial [5-7], antimicrobial [5,8], antifungal [9], antileukemic [10,11], antiviral and anti-HIV properties [12-15]. Anthraquinone and its derivatives are also used as antioxidants [16], dyes [17-20] or in photoimaging [20].

It has also been reported that amino-substituted anthraquinones show significantly increased antiproliferative activities against human/mammalian cancer cell lines [21,22] and are known to have potential antitumor activity, but are less toxic to normal cells and display low cardiotoxicity [23-26]. A study on 4-( $N$-cyclohexylamino)-emodin implied that it can discriminate well between hepatoma cells and primary hepatocytes and it retained the capacity to reverse the multi-drug-resistance phenotype [27]. Other aminoanthraquinone derivatives such as Reactive Blue 2 (RB-2), Acid Blue 25 (AB-25) and Acid Blue 129 (AB-129) also known as a good nucleotide-binding proteins [28] where RB-2 is one of the most widely used P2-receptor antagonists [29]. The potential of RB-2 was driven by its hydrophobic interactions of aromatic $\pi$-electron systems, and the hydrogen bonds with nitrogen as donor and acceptor atoms as these properties could block the P2-recptor.

Based on these promising bioactivities, the aim of this research was therefore to synthesise some new aminoantharaquinone derivatives with high potential as anticancer and antimicrobial agents. The effects of substrate amount, catalyst amount, reaction time and reaction temperature were studied. According to a study, shorter amines would result in lower cytotoxic effects [24] whereas the use of diamines or longer amine chains allow the possibility of forming side products due to their reactive properties [30]. Therefore, a simple straight chain amine containing four carbons $\left(\mathrm{BuNH}_{2}\right)$ was chosen for this study, while diacetoiodobenzene $\left[\mathrm{PhI}(\mathrm{OAc})_{2}\right]$ was used as catalyst because of it selectivity towards the substitution reaction [24]. Synthesised aminoanthraquinones were then further tested for cytotoxicity and antimicrobial activity.

\section{Results and Discussion}

The synthesis of aminoanthraquinone derivatives was achieved through two simple reaction steps. 1,4-Dihydroxyanthraquinone (1) was first subjected to methylation, reduction, and acylation to produce anthracene-1,4-dione (3) 1,4-dimethoxyanthracene-9,10-dione (5) and 9,10-dioxo-9,10-dihydroanthracene-1,4-diyl diacetate (7). Compounds $\mathbf{1}, \mathbf{3}, \mathbf{5}$ and 7 were then treated with butylamine $\left(\mathrm{BuNH}_{2}\right)$ using iodobenzenediacetate $\left[\mathrm{PhI}(\mathrm{OAc})_{2}\right]$ as catalyst to produce the desired aminoanthraquinones. All the compounds were elucidated using mp, IR, MS, 1D NMR, 2D NMR and comparison with data in the literature. The proposed mechanisms for the amination are also presented.

\subsection{Reduction, Methylation and Acylation}

The reduction of compound 1 using $\mathrm{NaBH}_{4}$ (1:1 equiv.) was performed successfully in 30 min to give a mixture of 4-hydroxyanthracene-1,10-dione (2) and anthracene-1,4-dione (3) in 69\% and 21\% yields, respectively. Increasing the amount of $\mathrm{NaBH}_{4}$ to 3 equiv. led to the formation of only compound 3 in excellent yield (Scheme 1 and Table 1). Further $\mathrm{NaBH}_{4}$ increases resulted in a lower yield of $\mathbf{3}$ as the single product obtained (Table 1, Entry I, II and III). 
The methylation of compound 1 with $\left(\mathrm{CH}_{3}\right)_{2} \mathrm{SO}_{4}$ in the presence of $\mathrm{K}_{2} \mathrm{CO}_{3}$ was achieved in acetone under reflux at $60{ }^{\circ} \mathrm{C}[31,32]$. The used of $\left(\mathrm{CH}_{3}\right)_{2} \mathrm{SO}_{4}$ as methylating agent is proven to give higher yields [33]. A mixture of 1-hydroxy-4-methoxyanthracene-9,10-dione (4) and 1,4-dimethoxyanthracene-9,10-dione (5) were obtained as yellow and orange solids, respectively (Table 1, Entry IV and $\mathrm{V}$ ). The ${ }^{1} \mathrm{H}-\mathrm{NMR}$ spectra of compounds 4 and $\mathbf{5}$ showed singlets at $\delta 3.76$ and $\delta 3.94 \mathrm{ppm}$, respectively, which were attributed to the methoxy protons.

Scheme 1. Reduction, methylation and acylation of $\mathbf{1 .}$<smiles>O=C1c2ccccc2C(=O)c2c(O)ccc(O)c21</smiles>

$1(1 \mathrm{eq})$<smiles>O=C1c2ccccc2C(=O)c2c(O)ccc(O)c21</smiles>

1 (1 eq)<smiles>O=C1c2ccccc2C(=O)c2c(O)ccc(O)c21</smiles>

1 (1 eq)

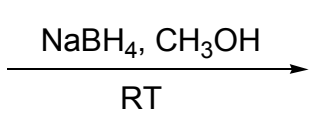

$\underset{\left(\mathrm{CH}_{3}\right)_{2} \mathrm{CO}, \text { reflux }}{\stackrel{\mathrm{K}_{2} \mathrm{CO}_{3}(11 \mathrm{eq}),\left(\mathrm{CH}_{3}\right)_{2} \mathrm{SO}_{4}(14 \mathrm{eq})}{\longrightarrow}}$

$\underset{\mathrm{Ac}_{2} \mathrm{O}(33 \mathrm{eq}), \mathrm{NaOAc}(1 \mathrm{eq})}{\longrightarrow}$<smiles>CC(=O)Oc1ccc(O)c2c1C(=O)c1ccccc1C2=O</smiles>

6<smiles>O=C1C=CC(=O)c2cc3ccccc3cc21</smiles>

3<smiles>COc1ccc(O)c2c1C(=O)c1ccccc1C2=O</smiles>

4<smiles>COc1ccc(OC)c2c1C(=O)c1ccccc1C2=O</smiles>

5

Table 1. Some effects on the reduction, methylation and acylation of $\mathbf{1}$.

\begin{tabular}{cccc}
\hline Entry & $\mathbf{N a B H}_{\mathbf{4}}$ (equiv.) & Reaction Time & Product (\% Yield) \\
\hline I & 1 & $30 \mathrm{~min}$ & $\mathbf{2}(69), \mathbf{3}(21)$ \\
II & 3 & $30 \mathrm{~min}$ & $\mathbf{3}(90)$ \\
III & 15 & $30 \mathrm{~min}$ & $\mathbf{3}(60)$ \\
\hline IV & - & $3 \mathrm{~h}$ & $\mathbf{4}(5), \mathbf{5}(85)$ \\
V & - & $4 \mathrm{~h}$ & $\mathbf{5}(96)$ \\
\hline VI & - & $2 \mathrm{~h}$ & $\mathbf{6}(26), \mathbf{7}(60)$ \\
VII & - & $3 \mathrm{~h}$ & $\mathbf{6}(15), \mathbf{7}(75)$ \\
VII & - & $9 \mathrm{~h}$ & $\mathbf{7}(90)$ \\
\hline
\end{tabular}

The acylation of compound $\mathbf{1}$ by using excess acetic acid anhydride in the presence of sodium acetate was completed in $2 \mathrm{~h}$ to obtain a mixture of 4-hydroxy-9,10-dioxo-9,10-dihydroanthracen-1-yl acetate (6) and 9,10-dioxo-9,10-dihydroanthracene-1,4-diyl diacetate (7) (Scheme 1). Increasing the reaction time for both methylation and acylation seemed to increase the dimethylated and diacetylated products, $\mathbf{5}$ and 7 (Table 1, Entry V, VI, VII and VIII). It was believed that the product of $\mathbf{3}, 5$ and 7 were produced through the intermediate compounds $\mathbf{2 , 4}$ and $\mathbf{6}$, respectively. 


\subsection{Amination}

Amination reactions were attempted using procedure of Teich et al. [24]. It was stated that the formation of aminoanthraquinones can be achieved in higher yield using 1.1 equiv. of the catalyst $\mathrm{PhI}(\mathrm{OAc})_{2}$. Compounds 1, 3, 5, and 7 (1 equiv.) were then used in a substitution reaction to produce aminoanthraquinones derivatives. The reaction was performed with excess $\mathrm{BuNH}_{2}$ in the presence of $\mathrm{PhI}(\mathrm{OAc})_{2}$ for $15 \mathrm{~min}$ to $6 \mathrm{~d}$ of reaction, depending on the hindrance of the starting material. $\mathrm{BuNH}_{2}$ also acted as a solvent for the reaction (Scheme 2). The catalytic effect was studied by performing the reaction either with or without the catalyst to observe what is the possible reaction or product that might occur or form. Therefore, direct amination of $\mathbf{1}$ with higher equivalents of butylamine in the presence of 1.1 equiv. of catalyst at RT gave a mixture of anthraquinone butylamines $\mathbf{1 a}$ and $\mathbf{1 b}$ in $1: 1$ ratio ( $78 \%$ yield). Reducing the equivalents of amine to half either with or without the catalyst produced a single product 1a in higher yield (70\%-90\%, Table 2, Entry I, II and III). However, increasing the reaction temperature gave a mixture of products again, where 1a was isolated as the major one (70\%). The butylamino group was observed to substitute at the ortho position or replace the $\mathrm{OH}$ group. The results proved that the amination occurred via a nucleophilic substitution reaction and in agreement with reported works $[21,25]$. The ${ }^{1} \mathrm{H}$ - and ${ }^{13} \mathrm{C}-\mathrm{NMR}$ spectra of $\mathbf{1 a}$ and $\mathbf{1 b}$ are also consistent with their structures and the reported data.

Scheme 2. Proposed mechanism of formation of $\mathbf{1 a}$ in the presence of catalyst.<smiles></smiles>

1

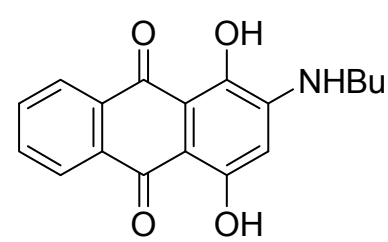

$1 a$<smiles>CCCCCCC</smiles>

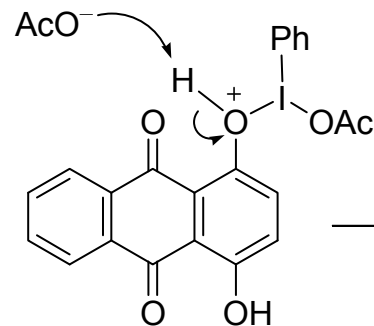

(n)

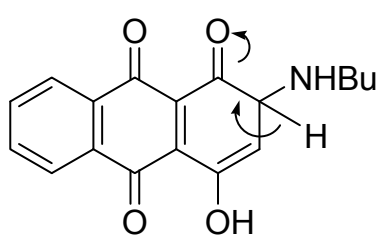

$+\quad \mathrm{Phl}(\mathrm{OAc}) \mathrm{H}$<smiles>O=C(O)[18OH]</smiles><smiles>[3H]C[Al-]C(=O)Oc1ccccc1</smiles><smiles>CC(C)(C)CCc1cc(O)c2c(c1O[Al](Cl)c1ccccc1)C(=O)c1ccccc1C2=O</smiles>

$+\mathrm{AcOH}$<smiles>CC(C)(C)C[NH2+][C@H]1C=C(O)C2=C1C(=O)c1ccccc1C2=O</smiles> 
Table 2. Effect of amine equivalence, catalyst and temperature on the amination of $1,3,5$ and 7.

\begin{tabular}{ccccc}
\hline Entry & BuNH $_{\mathbf{2}}$ (equiv.) & PhI(OAc) $\mathbf{2}$ (equiv.) & Temperature & Product (\% Yield) \\
\hline I & 450 & 1.1 & RT & $\mathbf{1 a}(40), \mathbf{1 b}(38)$ \\
II & 225 & 1.1 & RT & $\mathbf{1 a}(90)$ \\
III & 225 & - & RT & $\mathbf{1 a}(70)$ \\
IV & 225 & - & $80^{\circ} \mathrm{C}$ & $\mathbf{1 a}(70), \mathbf{b}(15)$ \\
\hline V & 225 & 1.1 & $\mathrm{RT}$ & $\mathbf{3 a}(60)$ \\
VI & 225 & - & $\mathrm{RT}$ & $\mathbf{3 a}(51)$ \\
VII & 112 & 1.1 & $\mathrm{RT}$ & $\mathbf{3 a}(46)$ \\
\hline VIII & 225 & 1.1 & $\mathrm{RT}$ & $\mathbf{5 a}(7), \mathbf{5 b}(10), \mathbf{5}(78)$ \\
IX & 225 & 1.1 & $80{ }^{\circ} \mathrm{C}$ & $\mathbf{5 c}(10), \mathbf{5 d}(73)$ \\
\hline X & 225 & 1.1 & $\mathrm{RT}$ & $\mathbf{1 a}(83)$ \\
XI & 225 & - & $\mathrm{RT}$ & $\mathbf{1 a}(55)$ \\
XII & 225 & - & $80{ }^{\circ} \mathrm{C}$ & $\mathbf{1 a}(46)$ \\
\hline
\end{tabular}

In the presence of $\mathrm{PhI}(\mathrm{OAc})_{2}$, the reaction proceeded with the interaction of the $\mathrm{OH}$ group of compound 1 with the catalyst to give the intermediate, O-IPh(OAc). Further attack by $\mathrm{BuNH}_{2}$ at the next carbon was produced $\mathrm{C}=\mathrm{O}$ and removed the $\mathrm{PhIOAc}$. Proton elimination then restored the double bond and $\mathrm{OH}$ of $1 \mathrm{a}$ (Scheme 2). In the absence of catalyst, the electron-donating nature of the $\mathrm{OH}$ group together with the electron delocalization made compound $\mathbf{1}$ easily attacked by the $\mathrm{BuNH}_{2}$ at the ortho-position to form $\mathbf{1 a}$ (Scheme 3).

Scheme 3. Proposed mechanism of formation of $\mathbf{1 a}$ without using a catalyst.

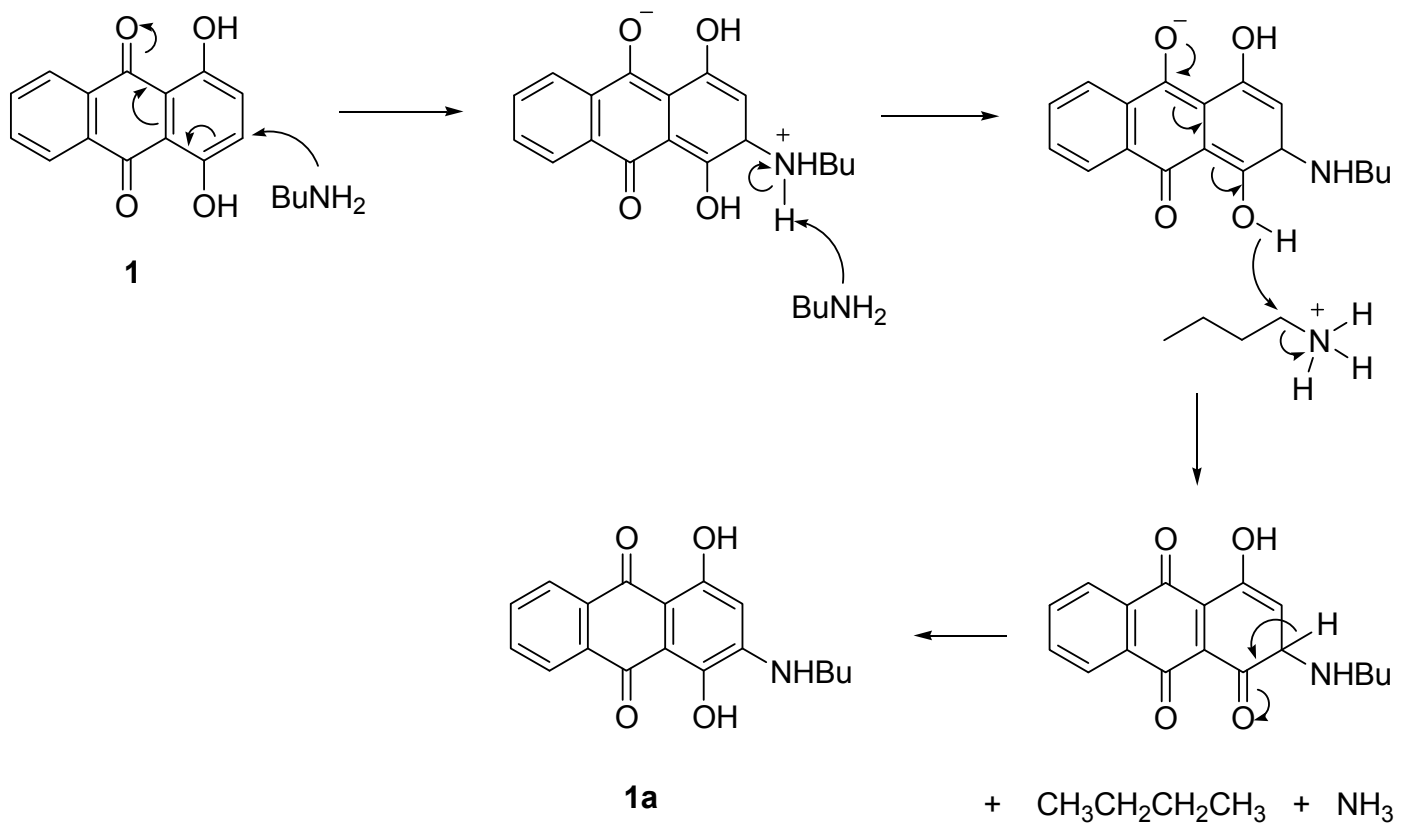

The compounds $\mathbf{1 a}, \mathbf{1 b}$ and the optimised amount of $\mathrm{BuNH}_{2}$ (225 equiv.) and $\mathrm{PhI}(\mathrm{OAc})_{2}$ (1.1 equiv.) were used as a comparison of nucleophilic substitution for amination of compounds $\mathbf{3}, \mathbf{5}$ and 7. Therefore, the effect of different 1,4-disubstituted of anthraquinones and the mechanisms were further investigated. 


\subsubsection{Amination of 3}

Amination of compound 3 produced a higher yield of 2-(butylamino)anthracene-1,4-dione (3a) when treated with 255 equiv. of $\mathrm{BuNH}_{2}$ (Scheme 4). It was observed that the yield decreased when the reaction was performed without a catalyst or if equivalents of amine were reduced (Table 2, Entry V, VI and VII).

Scheme 4. Amination of $1,3,5$, and 7 .<smiles>O=C1c2ccccc2C(=O)c2c(O)ccc(O)c21</smiles>

$1(1 \mathrm{eq})$<smiles>O=C1C=CC(=O)c2cc3ccccc3cc21</smiles>

3 (1 eq)

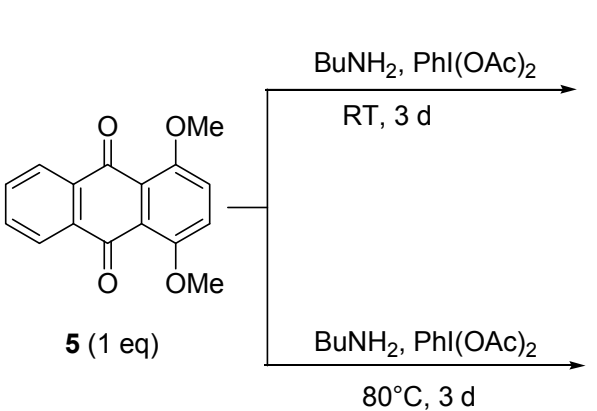

$80^{\circ} \mathrm{C}, 3 \mathrm{~d}$

$\underset{\mathrm{RT}, 15 \mathrm{~min}}{\stackrel{\mathrm{BuNH}_{2}, \mathrm{Phl}(\mathrm{OAc})_{2}}{\longrightarrow}}$<smiles>CCCCNC1=CC(=O)c2cc3ccccc3cc2C1=O</smiles>

$3 a$<smiles>CCCCNc1cc(OC)c2c(c1)C(=O)c1ccccc1C2=O</smiles>

$5 a$<smiles>CCCCNc1ccc(OC)c2c1C(=O)c1ccccc1C2=O</smiles>

$5 c$<smiles>CC(=O)Oc1ccc(OC(C)=O)c2c1C(=O)c1ccccc1C2=O</smiles>

7 (1 eq)

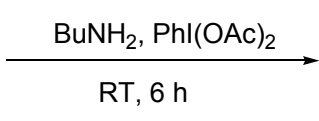<smiles>CCCCNc1cc(O)c2c(c1O)C(=O)c1ccccc1C2=O</smiles>

$1 a$<smiles>CCCCNc1ccc(O)c2c1C(=O)c1ccccc1C2=O</smiles>

$1 b$<smiles>CCCCNc1cc2c(cc1NCCCC)C(=O)c1ccccc1C2=O</smiles>

5b<smiles>CCCCNc1ccc(NCCC)c2c1C(=O)c1ccccc1C2=O</smiles>

$5 d$

The ${ }^{1} \mathrm{H}-\mathrm{NMR}$ spectrum of 3a showed aromatic proton singlets at $\delta 8.50$ and $\delta 8.48 \mathrm{ppm}$ that are attributed to the aromatic carbons at positions $\mathrm{C} 9$ and $\mathrm{C} 10$, respectively. A proton singlet observed at $\delta$ $5.80 \mathrm{ppm}$ indicated the presence of an unsaturated proton, whereas a broad singlet observed at $\delta 5.99$ ppm referred to the chelated proton of the amine. The ${ }^{13} \mathrm{C}$-NMR spectrum showed the presence of 18 signals correspond to the $18 \mathrm{C}$ in the structure. Higher chemical shifts were observed at $\delta 182.7$ and $\delta$ 181.4 ppm that represent the two $C=\mathrm{O}$ groups, whereas lower signals for $\mathrm{C} 2$ and $\mathrm{C} 3$ were observed at $\delta 130.2$ and $\delta 134.0 \mathrm{ppm}$. In comparison to the starting material, only one signal was observed for both $C=\mathrm{O}(\delta$ 184.7), and for $\mathrm{C} 2$ and $\mathrm{C} 3(\delta$ 140.1) due to the symmetrical structure of 3 . The position of the butylamino group of $\mathbf{3 a}$ was confirmed by an HMBC experiment which showed a ${ }^{3} J$ correlation as indicated in Figure 1. 
Figure 1. Selected HMBC correlation of $\mathbf{3 a}$ and $\mathbf{5 c}$.

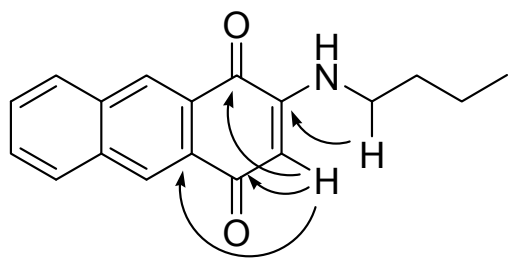

3a

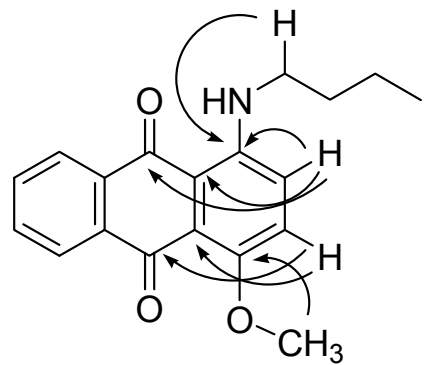

$5 c$

The proposed mechanism showed that $\mathrm{C} 3$ is positively charged and readily attacked by $\mathrm{BuNH}_{2}$ due to the resonance that drives by the interaction between the oxygen at $\mathrm{C} 1$ with the iodine of the catalyst. Further elimination of a proton at position $\mathrm{C} 3, \mathrm{PhI}$ and $\mathrm{AcOH}$ then restored the double bonds between $\mathrm{C}-\mathrm{C}$ and $\mathrm{C}-\mathrm{O}$ to give the product 3a (Scheme 5). A similar resonance effect is assumed to drive the $\mathrm{BuNH}_{2}$ to attack the $\mathrm{C} 3$ to produce a negatively charged oxygen for the reaction without catalyst. The reaction proceeded through a keto-enol tautomerism followed by elimination of $\mathrm{H}$ to give $\mathbf{3 a}$ (Scheme 6).

Scheme 5. Proposed mechanism of formation of 3a by using a catalyst.

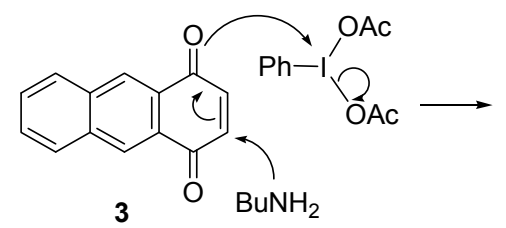

3 $\mathrm{BuNH}_{2}$

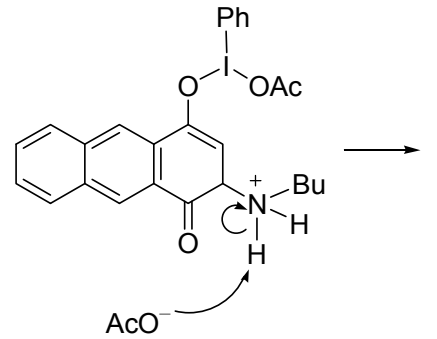

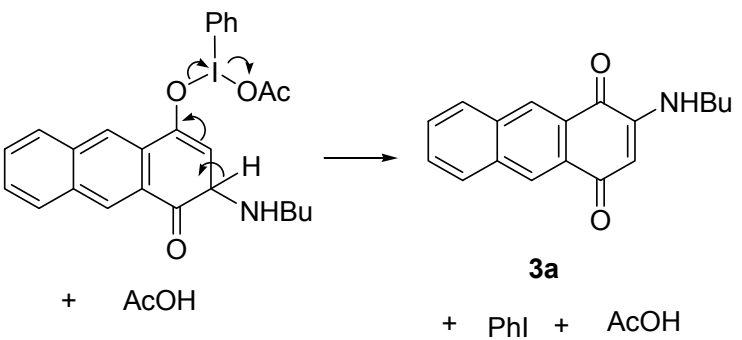

Scheme 6. Proposed mechanism for the formation of $\mathbf{3 a}$ (without catalyst).<smiles>NCCC1C(=O)c2cc3ccccc3cc2C(=O)C1CCN</smiles>

3

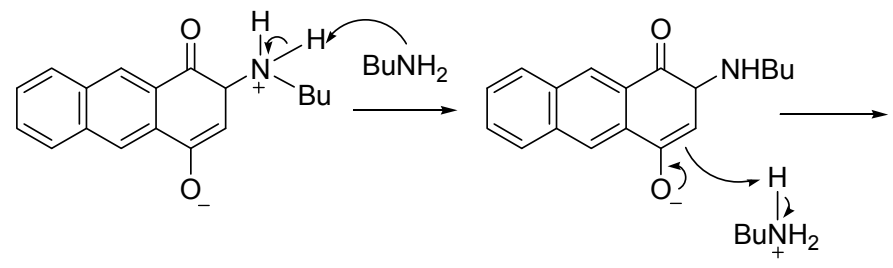

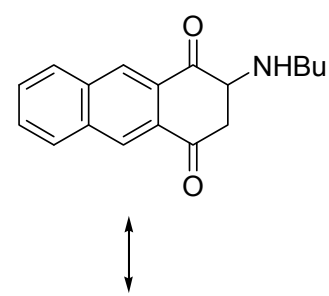
$\mathrm{CH}_{3} \mathrm{CH}_{2} \mathrm{CH}_{2} \mathrm{CH}_{3}+\mathrm{NH}_{3}+$<smiles>O=C1C=C(NCBr)C(=O)c2cc3ccccc3cc21</smiles>

3a

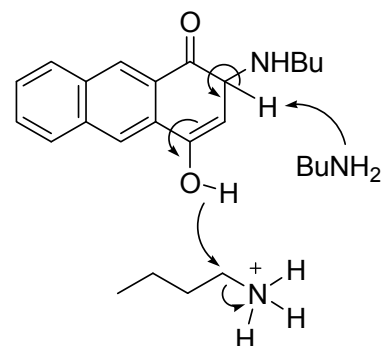

\subsubsection{Amination of 5}

Treatment of dimethoxyanthraquinone 5 with $\mathrm{BuNH}_{2}$ in the presence of $\mathrm{PhI}(\mathrm{OAc})_{2}$ produced four aminoathraquinones. At RT, a mixture of 2-(butylamino)-4-methoxyanthracene-9,10-dione (5a) and 
2,3-(dibutylamino)anthracene-9,10-dione (5b) was obtained in low yields (17\%) together with the unreacted starting material (78\%). A mixture of 1-(butylamino)-4-methoxyanthacene-9,10-dione (5c) and 1,4-(dibutylamino)anthracene-9,10-dione (5d) was produced at $80{ }^{\circ} \mathrm{C}$, in higher combined yield (83\%, Scheme 2). The diaminosubstituted products $\mathbf{5 b}$ and $\mathbf{5 d}$ were isolated as a major product (Table 2, Entry VIII and IX). It appears that the higher the temperature, the more the nucleophilic substitution selectivity. All four amino derivatives were easily separated by column chromatography (dichloromethane-petroleum ether/3:1). It seems that compound 5a and 5c which had same $R_{f}$ values and appearance $\left(R_{f} 0.33\right.$, dichloromethane-petroleum ether, $4: 1$; dark pink solid) were produced first as intermediates and then reacted further to form diaminoanthraquinones $\mathbf{5 b}$ and $\mathbf{5 d}$. Surprisingly, compounds $\mathbf{5 b}$ and $\mathbf{5 d}$ also shared same $R_{f}$ values 0.67 (dichloromethane-petroleum ether, 4:1) and both were obtained as dark blue solids.

The ${ }^{1} \mathrm{H}-\mathrm{NMR}$ spectra of $\mathbf{5 a}$ and $\mathbf{5 c}$ displayed signals attributed to methoxy protons at $\delta 3.98$ and $\delta$ $3.98 \mathrm{ppm}$, respectively. A broad singlet signal at $\delta 7.27 \mathrm{ppm}$ in the spectrum of $\mathbf{5 a}$ was assigned to the non-chelated amine proton, whereas for $\mathbf{5 c}$, the spectrum show a higher chemical shift at $\delta 9.84 \mathrm{ppm}$ which is due to the hydrogen bond between the amine hydrogen and carbonyl oxygen. Both compounds shared the same molecular formulae, $\mathrm{C}_{19} \mathrm{H}_{19} \mathrm{NO}_{3}$, as the mass spectra exhibited a molecular ion peak at $m / z$ 309. Selected HMBC correlations were shown in Figure 1.

The ${ }^{1} \mathrm{H}-\mathrm{NMR}$ of $\mathbf{5 d}$ showed the disappearance of the signal for the methoxy protons, which clearly indicated that nucleophilic aromatic substitution had occurred. The broad singlet at $\delta 10.73 \mathrm{ppm}$ was assigned to the chelated amine proton. The ${ }^{13} \mathrm{C}$-NMR showed the presence of 11 signals attributed to 22 carbons which are symmetrical. Four quaternary carbons were observed at $\delta 182.0(C=\mathrm{O}), 146.2$ $(C-\mathrm{C}=\mathrm{O}), 134.6(\mathrm{O}=\mathrm{C}-C)$ and $109.5 \mathrm{ppm}(C-\mathrm{NH})$. Three peaks at $\delta 123.5,126.0$ and $131.8 \mathrm{ppm}$ were assigned to methine aromatic carbons.

The reaction occurred as the methoxy group interacts with the catalyst. The positive charge on oxygen is then stabilized by the $\mathrm{C} 1-\mathrm{O}$ bond cleavage driven by the formation of $\mathrm{PhI}(\mathrm{OAc})\left(\mathrm{OCH}_{3}\right)$ and leaves the aromatic carbocation. With increasing heat, the carbocation is readily attacked by $\mathrm{BuNH}_{2}$ to produce $\mathbf{5 c}$ and $\mathbf{5 d}$. In contrast a slow reaction at RT favored the carbocation rearrangement to produce $\mathbf{5 a}$ and $\mathbf{5 b}$ (Scheme 7). This aromatic substitution of methoxy groups by amines is also supported by literature precedents $[21,25,28]$.

\subsubsection{Amination of 7}

2-(Butylamino)-1,4-dihydroxyanthracene-9,10-dione (1a) was successfully obtained in $83 \%$ yield under a similar amination approach applied to the acylated anthraquinone 7 (Scheme 4). The mechanism suggested that the acetate groups were reduced by the conditions and reagent used to give 1,4-dihydroxyanthraquinone (1) as an intermediate before it further reacted with $\mathrm{BuNH}_{2} / \mathrm{PhI}(\mathrm{OAc})_{2}$ to give 1a (Scheme 8). It was observed that 1a can still be obtained when the reaction was performed without catalyst or at $80{ }^{\circ} \mathrm{C}$ but gave lower yield. Heat applied to the reaction induced the reaction to be faster as the reaction time reduced from $6 \mathrm{~h}$ to $4 \mathrm{~h}$ (Table 2, Entry X, XI and XII). 
Scheme 7. Proposed mechanism of formation of $\mathbf{5 a}, \mathbf{5 b}, \mathbf{5 c}$ and $\mathbf{5 d}$.

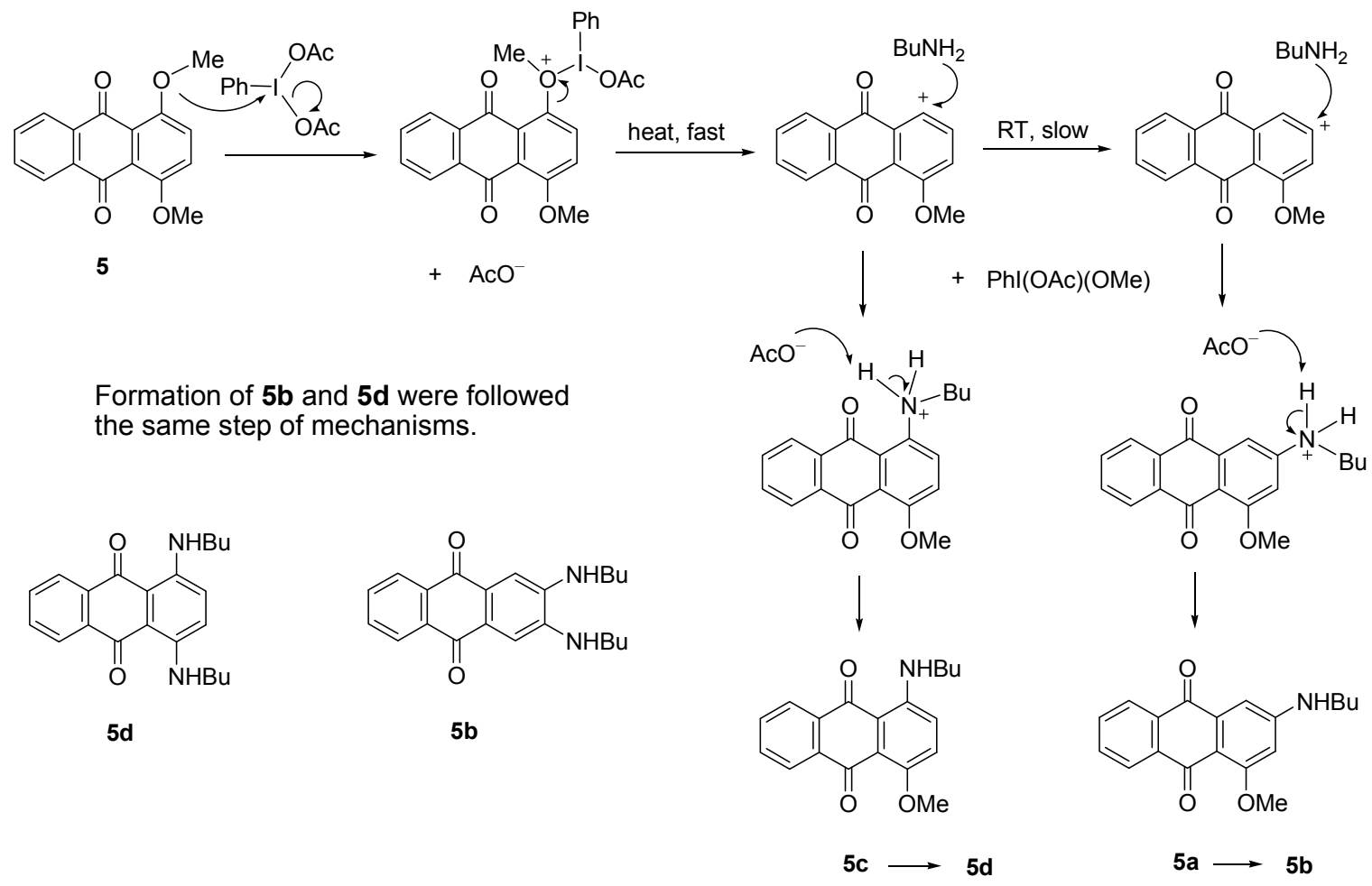

Scheme 8. Reduction of acyl group of 7 by butylamine.<smiles>CC(=O)Oc1ccc(OC(C)=O)c2c1C(=O)c1ccccc1C2=O</smiles>

7<smiles>CC(=O)Oc1ccc(OC(C)(C)C)c2c1C(=O)c1ccccc1C2=O</smiles>

$+\mathrm{BuNH}_{3}^{+}$<smiles>CCCCNC(C)(C)Oc1ccc(OC)c2c1C(=O)c1ccccc1C2=O</smiles><smiles>CC(=O)Oc1ccc([O-])c2c1C(=O)c1ccccc1C2=O</smiles>

$+\mathrm{MeCONHBu}$<smiles>CC(=O)Oc1ccc(O)c2c1C(=O)c1ccccc1C2=O</smiles>

6

The ${ }^{1} \mathrm{H}-\mathrm{NMR}$ for $1 \mathrm{a}$ showed the disappearance of the $\mathrm{COOCH}_{3}$ signal which proved that the acyl groups were reduced. This is also proven by the existence of strong chemical shifts at $\delta 14.23$ and $\delta$ $13.90 \mathrm{ppm}$ which represented the two chelated $\mathrm{OH}$. A broad singlet proton at $\delta 5.60 \mathrm{ppm}$ was attributed to the amine proton.

All three new aminoanthraquinones 3a, 5a and $\mathbf{5 b}$ were subjected to cytotoxic activity assays against MCF-7 (estrogen receptor positive human breast) and Hep-G2 (human hepatocellular liver carcinoma) cancer cell lines with compounds $\mathbf{3 a}$ and $\mathbf{5 a}$ being the most cytotoxic $\left(\mathrm{IC}_{50} 1.1-3.0 \mu \mathrm{g} / \mathrm{mL}\right)$. Increasing the number of amino substituents (compound $\mathbf{5 b}$ ) on the structure of anthraquinone basically reduced the activity against both MCF-7 and Hep-G2 cancer cell lines with $\mathrm{IC}_{50}$ of 3.0 and $13.0 \mu \mathrm{g} / \mathrm{mL}$, respectively (Table 3). Saha et al. [34] reported that the starting material, quinizarin 1 (free hydroxy groups) was not active towards MCF-7 but the methylated hydroxyl derivative of quinizarin showed some potential with $\mathrm{IC}_{50}$ values $70-80 \mu \mathrm{M}$. The results of this study also supported their finding where the presence of methoxy or amino groups enhanced the cytotoxic activity of the compounds. 
Table 3. Cytotoxic activity of aminoanthraquinones.

\begin{tabular}{ccc}
\hline \multirow{2}{*}{ Sample } & \multicolumn{2}{c}{ Cytotoxic Activity $\mathbf{I C}_{\mathbf{5 0}}(\boldsymbol{\mu g} / \mathbf{m L})$} \\
\cline { 2 - 3 } & MCF-7 & Hep-G2 \\
\hline 3a & 1.1 & 1.2 \\
$\mathbf{5 a}$ & 1.1 & 3.0 \\
$\mathbf{5 b}$ & 3.0 & 13.0 \\
\hline
\end{tabular}

Compounds 3a, 5c and $\mathbf{5 d}$ have been screened for antimicrobial activity using four different types of microbe, methicillin-resistant Staphylococcus aureus (MRSA), Pseudomonas aeruginosa, Candida albicans and Escherichia coli. The other two new compounds, $\mathbf{5 a}$ and $\mathbf{5 b}$ were replaced by compounds 5c and 5d due to insufficient materials and based on the similarity of their structures. All four compounds have the same methoxy and amino substituents and only differ at their amino positions. Therefore, it was assumed that all four compounds might give similar activity results. However, none of compounds had any effect on the growth of all four bacteria or the fungus.

\section{Experimental}

\subsection{General}

All chemicals are commercially available and were of analytical grade and used without purification unless otherwise stated. All reactions were monitored by TLC, using Silica gel 60 F245 (Merck KGaA) precoated aluminium backed plates and visualised by $\mathrm{UV}$ and $\mathrm{H}_{2} \mathrm{SO}_{4}$ solution. All organic extracts were dried over $\mathrm{Na}_{2} \mathrm{SO}_{4}$ and evaporated using rotary evaporator. Column chromatography was performed on silica gel 60. Melting points were recorded by digital melting point equipment (Electrothermal IA9000 Series). The IR spectra were obtained by using Perkin-Elmer FT-IR Model Spectrum 100 series spectrophotometer using UATR techniques and the adsorption bands were measured in the range of $280-4000 \mathrm{~cm}^{-1}$. MS spectra were recorded using equipped Shimadzu model QP5050A series. The 1D NMR and 2D NMR spectra were run on a JEOL machine at $400 \mathrm{MHz}$ or $500 \mathrm{MHz}$. All chemical shifts, $\delta$ were recorded in ppm relative to TMS signal. The coupling constants $J$ are given in $\mathrm{Hz}$.

\subsection{Reduction}

1,4-Dihydroxyanthraquinone (1, 1 equiv.) was dissolved in methanol (3 $\mathrm{mL})$ and stirred homogenously under a nitrogen atmosphere. Sodium borohydride (1, 3 or 15 equiv.) was added slowly to the reaction mixture and stirred for $30 \mathrm{~min}$. Water $(0.5 \mathrm{~mL})$ was added to the reaction mixture and the $\mathrm{pH}$ was adjusted to 5-6 with $1 \mathrm{M} \mathrm{HCl}$. Methanol was evaporated and the residue of aqueous layer was extracted with $\mathrm{CH}_{2} \mathrm{Cl}_{2}(3 \times 10 \mathrm{~mL})$. The combined organic layer were dried, filtered and evaporated under vacuum. The crude product was purified by column chromatography $\left(\mathrm{CH}_{2} \mathrm{Cl}_{2}\right.$-petroleum ether, 3:2) to obtain compounds $2\left(\mathrm{NaBH}_{4}: 1\right.$ equiv.) and $\mathbf{3}\left(\mathrm{NaBH}_{4}: 1,3\right.$ and 15 equiv.).

4-Hydroxyanthracene-1,10-dione (2). Dark orange powder (65.0 mg, 69\%); mp 205.8-206.1 ${ }^{\circ} \mathrm{C}$; $\mathrm{v}_{\max }$ (UATR) 3317, 3056, 1662, 1568, $1271 \mathrm{~cm}^{-1} ; \delta_{\mathrm{H}}\left(500 \mathrm{MHz}, \mathrm{CDCl}_{3}\right) 13.74(1 \mathrm{H}, \mathrm{s}, \mathrm{OH}), 8.44(1 \mathrm{H}, \mathrm{d}$, $J=8.0, \mathrm{CH}=\mathrm{C}), 8.03(1 \mathrm{H}, \mathrm{s}, \mathrm{CH}=\mathrm{C}), 7.91(1 \mathrm{H}, \mathrm{d}, J=8.0, \mathrm{CH}=\mathrm{C}), 7.64-7.69$ (2H, m, H-aromatic), 
$7.00\left(1 \mathrm{H}, \mathrm{d}, J=10.3, \mathrm{H}\right.$-aromatic), $6.96\left(1 \mathrm{H}, \mathrm{d}, \mathrm{J} 10.3, \mathrm{H}\right.$-aromatic); $\delta_{\mathrm{C}}\left(125 \mathrm{MHz}, \mathrm{CDCl}_{3}\right) 189.2$, $184.1,162.6,140.8,140.0,136.0,131.4,130.6,129.3,127.7,127.4,124.9,121.9,108.9 ; \mathrm{m} / z$ (EI) 224 $\left(\mathrm{M}^{+}, \mathrm{C}_{14} \mathrm{H}_{8} \mathrm{O}_{3}\right.$ requires 224).

Anthracene-1,4-dione (3). Orange powder (78.4 mg, 90\%); mp 216.4-217.2 ${ }^{\circ} \mathrm{C}$; $\mathrm{v}_{\max }$ (UATR) 3319, 3053, 1662, $1596 \mathrm{~cm}^{-1} ; \delta_{\mathrm{H}}\left(400 \mathrm{MHz}, \mathrm{CDCl}_{3}\right) 8.55(2 \mathrm{H}, \mathrm{s}, \mathrm{CH}=\mathrm{C}), 8.01(2 \mathrm{H}, \mathrm{dd}, J=2.8,6.4$, H-aromatic), $7.66\left(2 \mathrm{H}, \mathrm{dd}, J=2.8,6.4, \mathrm{H}\right.$-aromatic), $7.03\left(2 \mathrm{H}, \mathrm{s}, \mathrm{H}\right.$-aromatic); $\delta_{\mathrm{C}}\left(100 \mathrm{MHz}, \mathrm{CDCl}_{3}\right)$ 184.7, 140.1, 134.9, 130.3, 129.7, 128.9, 128.4; m/z (EI) $208\left(\mathrm{M}^{+}, \mathrm{C}_{14} \mathrm{H}_{8} \mathrm{O}_{3}\right.$ requires 208).

\subsection{Methylation}

A mixture of 1 (1 equiv.), $\mathrm{K}_{2} \mathrm{CO}_{3}$ (11 equiv.) and $\left(\mathrm{CH}_{3}\right)_{2} \mathrm{SO}_{4}$ (14 equiv.) in acetone $(5 \mathrm{~mL})$ was refluxed for $3 \mathrm{~h}$. The reaction mixture was added to $25 \mathrm{~mL}$ of $2 \mathrm{M} \mathrm{HCl}$ and extracted with EtOAc $(3 \times 25 \mathrm{~mL})$. The combined organic layers were dried, filtered and evaporated under vacuum. The crude product was purified by column chromatography $\left(\mathrm{CH}_{2} \mathrm{Cl}_{2}\right.$-petroleum ether, 4:1) to produce compounds $\mathbf{4}$ and $\mathbf{5}$.

1-Hydroxy-4-methoxyanthracene-9,10-dione (4). Orange powder (5.3 mg, 5\%); mp 162-163 ${ }^{\circ} \mathrm{C}$; vmax (UATR) 3073, 2924, 1667, 1590, 1440, 1234, $1178 \mathrm{~cm}^{-1} ; \delta \mathrm{H}(400 \mathrm{MHz}, \mathrm{CDCl} 3) 12.71(1 \mathrm{H}, \mathrm{s}, \mathrm{OH})$, $8.01(2 \mathrm{H}, \mathrm{t}, J=6.4, \mathrm{H}$-aromatic) $7.52(2 \mathrm{H}, \mathrm{dt}, J=19.3,6.4, \mathrm{H}$-aromatic), $7.15(1 \mathrm{H}, \mathrm{d}, J=9.2$, $\mathrm{H}$-aromatic), $7.06(1 \mathrm{H}, \mathrm{d}, J=10.1, \mathrm{H}$-aromatic), $3.76(3 \mathrm{H}, \mathrm{s}, \mathrm{OCH} 3) ; \delta \mathrm{C} 188.8,181.5,157.2,154.1$, $134.9,134.6,133.1,132.1,127.2,126.2,126.2,123.5,119.0,115.8,56.9$ (100 MHz, CDCl3); m/z (EI) $254(\mathrm{M}+, \mathrm{C} 15 \mathrm{H} 10 \mathrm{O} 4$ requires 254$)$.

1,4-Dimethoxyanthracene-9,10-dione (5). Yellow powder (108.1 mg, 96\%); $\mathrm{mp} 198-200{ }^{\circ} \mathrm{C} ; \mathrm{v}_{\max }$ (UATR) 3089, 2998, 1668, 1566, 1404, $1243 \mathrm{~cm}^{-1}$; $\delta_{\mathrm{H}}\left(400 \mathrm{MHz}, \mathrm{CDCl}_{3}\right) 8.10(2 \mathrm{H}, \mathrm{dd}, J=5.5,3.6$ $\mathrm{H}$-aromatic), $7.65\left(2 \mathrm{H}, \mathrm{dd}, J=5.5,3.6 \mathrm{H}\right.$-aromatic), $7.28\left(2 \mathrm{H}, \mathrm{s}, \mathrm{H}\right.$-aromatic), $3.94\left(6 \mathrm{H}, \mathrm{s}, \mathrm{OCH}_{3}\right) ; \delta_{\mathrm{C}}$ $\left(100 \mathrm{MHz}, \mathrm{CDCl}_{3}\right) 183.5,154.2,134.3,133.4,126.5,123.1,120.3,57.1 ; \mathrm{m} / \mathrm{z}(\mathrm{EI}) 268\left(\mathrm{M}^{+}, \mathrm{C}_{16} \mathrm{H}_{12} \mathrm{O}_{4}\right.$ requires 268 ).

\subsection{Acylation}

A mixture of compound 1 ( 1 equiv.), $\mathrm{Ac}_{2} \mathrm{O}$ (33 equiv.), and $\mathrm{NaOAc}$ ( 1 equiv) was stirred at $100{ }^{\circ} \mathrm{C}$ for $2 \mathrm{~h}$. The reaction mixture were added to ice cold water and extracted with $\mathrm{CH}_{2} \mathrm{Cl}_{2}(3 \times 25 \mathrm{~mL})$. The combined organic layers was dried and evaporated under vacuum. The crude product was purified by column chromatography $\left(\mathrm{CH}_{2} \mathrm{Cl}_{2}\right.$-petroleum ether, 3:1) to produce compounds 6 and 7.

4-Hydroxy-9,10-dioxo-9,10-dihydroanthracen-1-yl acetate (6). Light orange powder (31.8 mg, 26\%); mp 189.1-189.5 ${ }^{\circ} \mathrm{C}$; $\mathrm{v}_{\max }$ (UATR) 3535, 2935, 1772, 1667, 1587, 1360, 1168, $1011 \mathrm{~cm}^{-1} ; \delta_{\mathrm{H}}(400$ $\left.\mathrm{MHz}, \mathrm{CDCl}_{3}\right) 13.04(1 \mathrm{H}, \mathrm{s}, \mathrm{OH}), 8.28(1 \mathrm{H}, \mathrm{t}, J=4.6, \mathrm{H}$-aromatic), 8.21 (1H, t, $J=4.6$, H-aromatic), $7.79\left(2 \mathrm{H}, \mathrm{t}, J=3.7, \mathrm{H}\right.$-aromatic), $7.33\left(2 \mathrm{H}, \mathrm{s}, \mathrm{H}\right.$-aromatic), $2.46\left(3 \mathrm{H}, \mathrm{s}, \mathrm{OCH}_{3}\right) ; \delta_{\mathrm{C}}\left(100 \mathrm{MHz}, \mathrm{CDCl}_{3}\right)$ $188.5,181.2,169.9,161.3,143.2,135.0,134.1,133.5,132.5,131.22,127.4,126.8,126.0,123.5$, $115.9,21.2 ; \mathrm{m} / \mathrm{z}(\mathrm{EI}) 282\left(\mathrm{M}^{+}, \mathrm{C}_{16} \mathrm{H}_{10} \mathrm{O}_{5}\right.$ requires 282$)$. 
9,10-Dioxo-9,10-dihydroanthracene-1,4-diyl diacetate (7). Light yellow powder (122.4 mg, 90\%); mp 236.2-237.0 ${ }^{\circ} \mathrm{C} ; \mathrm{v}_{\max }$ (UATR) 3081, 1762, 1667, 1582, 1437, $1177 \mathrm{~cm}^{-1} ; \delta_{\mathrm{H}}\left(400 \mathrm{MHz}, \mathrm{CDCl}_{3}\right) 8.14(2 \mathrm{H}, \mathrm{dd}$, $J=5.5,3.7 \mathrm{H}$-aromatic), $7.73(2 \mathrm{H}, \mathrm{dd}, J=5.5,3.7$, H-aromatic), 7.41 (1H, s, H-aromatic), 2.47 (6H, s, $\left.\mathrm{OCCH}_{3}\right) ; \delta_{\mathrm{C}}\left(100 \mathrm{MHz}, \mathrm{CDCl}_{3}\right) 181.6,169.6,148.3,134.2,133.4,131.1,127.0,126.2,21.3 ; \mathrm{m} / \mathrm{z}(\mathrm{EI})$ $324\left(\mathrm{M}^{+}, \mathrm{C}_{16} \mathrm{H}_{10} \mathrm{O}_{5}\right.$ requires 324).

\subsection{Amination-General Procedure}

Butylamine (112, 225 or 450 equiv.) was added dropwise to a mixture of $\mathbf{1 , 3}, \mathbf{5}$, or 7 (1 equiv.) and $\mathrm{PhI}(\mathrm{OAc})_{2}\left(0.41 \mathrm{mmol}\right.$, or without catalyst) at RT (or heated at $80{ }^{\circ} \mathrm{C}$ ) and stirred for $15 \mathrm{~min}$ to $3 \mathrm{~d}$. The reaction mixture, $25 \mathrm{~mL} 10 \mathrm{M} \mathrm{HCl}$ and $\mathrm{NaHCO}_{3}(84 \mathrm{~mL})$ were added to ice cold water $(84 \mathrm{~mL})$ successively. The resulting solution was extracted with EtOAc $(3 \times 25 \mathrm{~mL})$. The organic layer was washed with $\mathrm{H}_{2} \mathrm{O}(3 \times 25 \mathrm{~mL})$, dried and evaporated. The crude product was then chromatographed on silica gel (DCM-petroleum ether, 4:1) to give a mixture of amine derivatives of anthraquinone 1a, $\mathbf{1 b}$, 3a, 5a-d.

2-(Butylamino)-1,4-dihydroxyanthracene-9,10-dione (1a). Dark pink powder (176.0 mg, 90\%); mp 158.0-158.4 ${ }^{\circ} \mathrm{C}$; $\mathrm{v}_{\max }$ (UATR) 3378, 3308, 2949, 1635, 1565, 1516, 1459, 1417, 1260, $1156 \mathrm{~cm}^{-1}$; $\delta_{\mathrm{H}}\left(500 \mathrm{MHz} \mathrm{CDCl}_{3}\right) 14.23(1 \mathrm{H}, \mathrm{s}, \mathrm{OH}) 13.90(1 \mathrm{H}, \mathrm{s}, \mathrm{OH}), 8.28(1 \mathrm{H}, \mathrm{d}, J=6.9, \mathrm{H}$-aromatic $), 8.25$ (1H, d, $J=6.9$, H-aromatic), 7.75 (1H, t, $J=5.8, \mathrm{H}$-aromatic), 7.68 (1H, t, $J=5.8$, H-aromatic), 6.05 $\left(1 \mathrm{H}, \mathrm{s}, \mathrm{H}\right.$-aromatic), $5.57\left(1 \mathrm{H}\right.$, br. s, NH), $3.21\left(2 \mathrm{H}, \mathrm{q}, J=6.9, \mathrm{NHCH}_{2} \mathrm{CH}_{2}\right), 1.65-1.72(2 \mathrm{H}, \mathrm{m}$, $\left.\mathrm{CH}_{2} \mathrm{CH}_{2} \mathrm{CH}_{2}\right), 1.42-1.50\left(2 \mathrm{H}, \mathrm{m}, \mathrm{CH}_{2} \mathrm{CH}_{2} \mathrm{CH}_{3}\right), 0.98\left(3 \mathrm{H}, \mathrm{t}, \mathrm{J} 6.9, \mathrm{CH}_{2} \mathrm{CH}_{3}\right) ; \delta_{\mathrm{C}}\left(125 \mathrm{MHz}, \mathrm{CDCl}_{3}\right)$ 183.5, 178.0, 166.5, 153.6, 147.7, 134.7, 134.0, 132.4, 132.3, 126.5, 126.3, 110.4, 102.9, 100.3, 42.8, 30.7, 20.3, 13.7; m/z (EI) $311\left(\mathrm{M}^{+}, \mathrm{C}_{18} \mathrm{H}_{17} \mathrm{NO}_{4}\right.$ requires 311).

1-(Butylamino)-4-hydroxyanthracene-9,10-dione (1b). Dark purple powder (31.5 mg, 38\%); mp 127.2-127.9 ${ }^{\circ} \mathrm{C} ; \mathrm{v}_{\max }$ (UATR) 3170, 2954, 2926, 2853, 1616, 1580, 1463, 1233, $1162 \mathrm{~cm}^{-1} ; \delta_{\mathrm{H}}$ $\left(500 \mathrm{MHz}, \mathrm{CDCl}_{3}\right) 13.71(1 \mathrm{H}, \mathrm{s}, \mathrm{OH}) 10.29(1 \mathrm{H}$, br. s, NH), 8.30 (2H, dd, J=8.0, 16.0, H-aromatic), 7.77 (1H, t $J=5.7, \mathrm{H}$-aromatic), 7.70 (1H, t $J=5.8, \mathrm{H}$-aromatic), 7.21 (1H, s, H-aromatic), 7.20 (1H, s, H-aromatic), $3.36\left(2 \mathrm{H}, \mathrm{t}, J=6.9, \mathrm{NHCH}_{2} \mathrm{CH}_{2}\right), 1.70-1.77\left(2 \mathrm{H}, \mathrm{m}, \mathrm{CH}_{2} \mathrm{CH}_{2} \mathrm{CH}_{2}\right), 1.47-1.55(2 \mathrm{H}, \mathrm{m}$, $\left.\mathrm{CH}_{2} \mathrm{CH}_{2} \mathrm{CH}_{3}\right), 0.99\left(3 \mathrm{H}, \mathrm{t}, J=6.9, \mathrm{CH}_{2} \mathrm{CH}_{3}\right) ; \delta_{\mathrm{C}}\left(125 \mathrm{MHz}, \mathrm{CDCl}_{3}\right)$ 187.5, 182.0, 156.8, 147.7, 135.5, $134.2,132.7,132.5,129.0,126.7,126.4,124.1,113.8,108.4,42.7,31.6,20.4,13.9 ; \mathrm{m} / \mathrm{z}$ (EI) 311 $\left(\mathrm{M}^{+}, \mathrm{C}_{18} \mathrm{H}_{17} \mathrm{NO}_{3}\right.$ requires 295).

2-(Butylamino)anthracene-1,4-dione (3a). Yellow powder, (70.1 mg, 60\%); mp 173.4-173.9 ${ }^{\circ} \mathrm{C}$; $\mathrm{v}_{\max }$ (UATR) 3325, 2926, 1677, 1573, 1504, 1456, 1406, 1319, $1250 \mathrm{~cm}^{-1} ; \delta_{\mathrm{H}}\left(500 \mathrm{MHz}, \mathrm{CDCl}_{3}\right) 8.50(1 \mathrm{H}, \mathrm{s}$, $\mathrm{H}$-aromatic), $8.48(1 \mathrm{H}, \mathrm{s}, \mathrm{H}$-aromatic), $7.93(2 \mathrm{H}, \mathrm{t}, J=8.0, \mathrm{H}$-aromatic), $7.59(1 \mathrm{H}, \mathrm{t}, J=5.8$, $\mathrm{H}$-aromatic), 7.55 (1H, d, $J=8.1$, H-aromatic), $5.99(1 \mathrm{H}$, br. s, NH), $5.80(1 \mathrm{H}, \mathrm{s}, \mathrm{CH}=\mathrm{C}), 3.16(2 \mathrm{H}, \mathrm{q}$, $\left.J=6.9, \mathrm{NHCH}_{2} \mathrm{CH}_{2}\right), 1.62-1.69\left(2 \mathrm{H}, \mathrm{m}, \mathrm{CH}_{2} \mathrm{CH}_{2} \mathrm{CH}_{2}\right), 1.37-1.46\left(2 \mathrm{H}, \mathrm{m}, \mathrm{CH}_{2} \mathrm{CH}_{2} \mathrm{CH}_{3}\right), 0.94(3 \mathrm{H}, \mathrm{t}$, $\left.J=6.9, \mathrm{CH}_{2} \mathrm{CH}_{3}\right) ; \delta_{\mathrm{C}}\left(125 \mathrm{MHz}, \mathrm{CDCl}_{3}\right) 182.7,181.4,149.1,135.7,134.0,130.2,130.0,129.8,129.6$, 129.0, 128.7, 127.7, 127.6, 102.6, 42.4, 30.4, 20.3, 13.8; m/z (EI) $279\left(\mathrm{M}^{+}, \mathrm{C}_{18} \mathrm{H}_{17} \mathrm{NO}_{2}\right.$ requires 279). 
2-(Butylamino)-4-methoxyanthracene-9,10-dione (5a). Dark purple powder (12.5 mg, 10\%); mp 87.8-88.2 ${ }^{\circ} \mathrm{C} ; \mathrm{v}_{\max }(\mathrm{UATR}) 3535,2936,1630,1590,1506,1461,1354,1250,1180 \mathrm{~cm}^{-1} ; \delta_{\mathrm{H}}(400$ $\left.\left.\mathrm{MHz}, \mathrm{CDCl}_{3}\right)\right) 8.23(1 \mathrm{H}, \mathrm{t}, J=2.8, \mathrm{H}$-aromatic), 8.21 (1H, t, $J=2.8, \mathrm{H}$-aromatic), 7.70 (2H, t, $J=3.6$, H-aromatic), 7.37 (1H, d, $J=9.2, \mathrm{H}$-aromatic), 7.27 (1H, d, $J=10.1$, H-aromatic), 5.29 (1H, br. s, $\mathrm{NH}), 3.98\left(3 \mathrm{H}, \mathrm{s}, \mathrm{OCH}_{3}\right), 3.33\left(2 \mathrm{H}, \mathrm{t}, J=7.3, \mathrm{NHCH}_{2} \mathrm{CH}_{2}\right), 1.73-1.82\left(2 \mathrm{H}, \mathrm{m}, \mathrm{CH}_{2} \mathrm{CH}_{2} \mathrm{CH}_{2}\right)$, 1.46-1.57 (2H, m, $\left.\mathrm{CH}_{2} \mathrm{CH}_{2} \mathrm{CH}_{3}\right), 0.99\left(3 \mathrm{H}, \mathrm{t}, J=7.3, \mathrm{CH}_{2} \mathrm{CH}_{3}\right) ; \delta_{\mathrm{C}}\left(100 \mathrm{MHz}, \mathrm{CDCl}_{3}\right) 185.3,183.3$, 152.7, 145.6, 134.5, 134.0, 133.3, 133.2, 126.8, 126.2, 124.1, 121.7, 121.4, 114.0, 57.6, 44.1, 31.1, 20.4, 13.9; m/z (EI) $309\left(\mathrm{M}^{+}, \mathrm{C}_{19} \mathrm{H}_{19} \mathrm{NO}_{3}\right.$ requires 309).

2,3-(Dibutylamino)anthracene-9,10-dione (5b). Dark blue powder (10.6 mg, 7\%); mp 113.0-113.6 ${ }^{\circ} \mathrm{C}$; $\mathrm{v}_{\max }(\mathrm{UATR}) 3539,2929,1669,1583,1522,1364,1249,1172 \mathrm{~cm}^{-1} ; \delta_{\mathrm{H}}\left(500 \mathrm{MHz}, \mathrm{CDCl}_{3}\right) 8.29(2 \mathrm{H}$, $\mathrm{dd}, J=5.7,3.4$, H-aromatic), $7.76(2 \mathrm{H}, \mathrm{d}, J=5.7,3.4$, H-aromatic), 7.50 (2H, s, H-aromatic), 5.29 $(2 \mathrm{H}, \mathrm{s}, \mathrm{NH}), 3.36\left(4 \mathrm{H}, \mathrm{t}, J=6.9, \mathrm{NHCH}_{2} \mathrm{CH}_{2}\right), 1.79-1.85\left(4 \mathrm{H}, \mathrm{m}, \mathrm{CH}_{2} \mathrm{CH}_{2} \mathrm{CH}_{2}\right), 1.47-1.54(4 \mathrm{H}, \mathrm{m}$, $\left.\mathrm{CH}_{2} \mathrm{CH}_{2} \mathrm{CH}_{3}\right), 0.99\left(6 \mathrm{H}, \mathrm{t}, J=6.9, \mathrm{CH}_{2} \mathrm{CH}_{3}\right) ; \delta_{\mathrm{C}}\left(500 \mathrm{MHz}, \mathrm{CDCl}_{3}\right)$ 184.5, 141.6, 133.8, 133.7, 126.8, 125.4, 114.7 , 45.9, 30.6, 20.3, 13.8; m/z (EI) $350\left(\mathrm{M}^{+}, \mathrm{C}_{22} \mathrm{H}_{26} \mathrm{~N}_{2} \mathrm{O}_{2}\right.$ requires 350).

1-(Butylamino)-4-methoxyanthacene-9,10-dione (5c). Dark purple powder (11.4 mg, 10\%); mp 96.3-96.9 ${ }^{\circ} \mathrm{C}$; $\mathrm{v}_{\max }$ (UATR) 3536, 2929, 1647, 1591, 1506, 1461, 1356, 1248, $1180 \mathrm{~cm}^{-1} ; \delta_{\mathrm{H}}$ $\left(500 \mathrm{MHz}, \mathrm{CDCl}_{3}\right) 9.84(1 \mathrm{H}, \mathrm{s}, \mathrm{NH}), 8.17(2 \mathrm{H}, \mathrm{dd}, J=16.9,2.3, \mathrm{H}$-aromatic), 7.60-7.67 (2H, m, $\mathrm{H}$-aromatic), 7.27 (1H, d, $J=9.2, \mathrm{H}$-aromatic), 7.02 (1H, d, $J=9.2$, H-aromatic), 3.92. (3H, s, $\left.\mathrm{OCH}_{3}\right)$, $3.23\left(2 \mathrm{H}, \mathrm{q}, J=6.9, \mathrm{NHCH}_{2} \mathrm{CH}_{2}\right), 1.66-1.71\left(2 \mathrm{H}, \mathrm{m}, \mathrm{CH}_{2} \mathrm{CH}_{2} \mathrm{CH}_{2}\right), 1.43-1.51\left(2 \mathrm{H}, \mathrm{m}, \mathrm{CH}_{2} \mathrm{CH}_{2} \mathrm{CH}_{3}\right)$, $0.96\left(3 \mathrm{H}, \mathrm{t}, J=6.9, \mathrm{CH}_{2} \mathrm{CH}_{3}\right) ; \delta_{\mathrm{C}}\left(125 \mathrm{MHz}, \mathrm{CDCl}_{3}\right) 184.8,183.4,151.6,147.5,134.4,134.2,133.0$, $132.8,126.6,126.1,124.3,121.1,120.2,112.3,57.5,42.8,31.4,20.5,13.9 ; \mathrm{m} / \mathrm{z}$ (EI) 309 $\left(\mathrm{M}^{+}, \mathrm{C}_{19} \mathrm{H}_{19} \mathrm{NO}_{3}\right.$ requires 309).

1,4-(Dibutylamino)anthracene-9,10-dione (5d). Dark blue powder (94.5 mg, 73\%); mp 113.5-114.2 ${ }^{\circ} \mathrm{C}$; $\mathrm{v}_{\max }$ (UATR) 3747, 2927, 1641, 1570, 1518, 1461, 1364, $1258 \mathrm{~cm}^{-1} ; \delta_{\mathrm{H}}\left(500 \mathrm{MHz}, \mathrm{CDCl}_{3}\right) 10.73(2 \mathrm{H}$, br. s, NH), 8.28 (2H, dd, J 5.7, 3.4, H-aromatic), 7.62 (2H, dd, J= 5.7, 3.4, H-aromatic), 7.04 (2H, s, H-aromatic), 3.25-3.29 (4H, m, $\left.\mathrm{NHCH}_{2} \mathrm{CH}_{2}\right), 1.65-1.71\left(4 \mathrm{H}, \mathrm{m}, \mathrm{CH}_{2} \mathrm{CH}_{2} \mathrm{CH}_{2}\right), 1.43-1.51(4 \mathrm{H}, \mathrm{m}$, $\left.\mathrm{CH}_{2} \mathrm{CH}_{2} \mathrm{CH}_{3}\right), 0.96\left(6 \mathrm{H}, \mathrm{t}, J=6.9, \mathrm{CH}_{2} \mathrm{CH}_{3}\right) ; \delta_{\mathrm{C}}\left(125 \mathrm{MHz}, \mathrm{CDCl}_{3}\right)$ 182.0, 146.2, 134.6, 131.8, 126.0, 123.5, 109.5 , 42.6, 31.8, 20.5, 14.0; m/z (EI) $350\left(\mathrm{M}^{+}, \mathrm{C}_{22} \mathrm{H}_{26} \mathrm{~N}_{2} \mathrm{O}_{2}\right.$ requires 350).

\subsection{Cytotoxic Assays}

The cytotoxic assay was carried out according to the method described by Sukari et al. [35]. The MCF-7 (estrogen receptor positive human breast) and Hep-G2 (human hepatocellular liver carcinoma) cancer cells were purchased from ATCC. The cells were grown and maintained in RPMI 1640 media, supplemented with $10 \%$ fetal calf serum (FCS) and 1\% antibiotic penicillin-streptomycin in an atmosphere of $5 \% \mathrm{CO}_{2}$ at $37{ }^{\circ} \mathrm{C}$. The medium was used to dilute the cells to a concentration of $5 \times 10^{5}$ cells $/ \mathrm{mL}$. From this cells suspension, $100 \mu \mathrm{L}$ of various concentrations of the synthesised compounds were pipetted into a 96-well micro titer plate and incubated in $37{ }^{\circ} \mathrm{C}, 5 \% \mathrm{CO}_{2}$ incubator for $72 \mathrm{~h}$. The various concentration used were 100, 50, 25, 12.5, 6.25, 3.125, $1.56 \mu \mathrm{g} / \mathrm{mL}$. The assay of each concentration of synthesised compounds was performed in triplicate and the control wells of 
untreated population were also included. After three $d$, the fraction of surviving cells was determined relative to the untreated cells population by the colorimetric MTT (3-(4,5-dimethylthiazol-2-yl)-2,5diphenyltetrazolium bromide) method where the viability of cells was measured by $20 \mu \mathrm{L}$ of blue formazan crystals of MTT solution $(5 \mathrm{mg} / \mathrm{mL}$ in phosphate-buffered saline, PBS) added to each well followed by incubation in $37{ }^{\circ} \mathrm{C}, 5 \% \mathrm{CO}_{2}$ incubator for $3-4 \mathrm{~h} .100 \mu \mathrm{L}$ of cells suspension or cells monolayer in each micro titer was removed from each well. The plate was left at room temperature for 30 min before reading the absorbance. The absorbance was read with the multiwell scanning spectrophotometer (ELISA reader) test wavelength of $570 \mathrm{~nm}$ and reference wavelength of $630 \mathrm{~nm}$. The cytotoxic index used was $\mathrm{IC}_{50}$ which is the concentration that yield $50 \%$ inhibition of the cells compared with untreated control.

\subsection{Antimicrobial Assay}

The modified disc diffusion method was followed a procedure by Garba and Okeniyi [36]. Nutrient agar ( $20 \mathrm{~g}$ ) was suspended in $1 \mathrm{~L}$ of distilled water and stirred. It was boiled to dissolve homogenously and autoclaved at $121^{\circ} \mathrm{C}$ for $20 \mathrm{~min}$. The agar was allowed to cool to $50{ }^{\circ} \mathrm{C}$ and poured into sterile disposable petri dishes. Four microbes, methicillin-resistant Staphylococcus aureaus (MRSA), Pseudomonas aeruginosa, Candida albicans and Escherichia coli were inoculated into prepared nutrient broth and incubated at $37{ }^{\circ} \mathrm{C}$ for overnight. The suspension of the microbes in the broth was inoculated on the nutrient agar using sterile cotton bud. The sterile $6 \mathrm{~mm}$ paper discs were impregnated with the synthesised compounds in concentrations of $20,10,5,2,1,0.5$ and $0.1 \mathrm{mg} / \mathrm{mL}$ and allowed to soak for $1 \mathrm{~min}$. The paper discs were removed, dried and placed on the surface of agar plates inoculated with the microbial cultures. Each synthesised compound was tested in triplicate. Paper discs impregnated with acetone were used as a negative control. The petri dishes were incubated in inverted position at $37{ }^{\circ} \mathrm{C}$ for $24 \mathrm{~h}$. The zones of inhibitions (clear area without bacterial growth) were measured in $\mathrm{cm}$.

\section{Conclusions}

Aminoantraquinone derivatives were synthesised through methylation, reduction or acylation then followed by amination. In total, seven aminoanthraquinones (compounds 1a, 1b, 3a, and 5-d) were produced, including three new compounds: 2-(butylamino)anthracene-1,4-dione (3a), 2-(butyl- amino)anthracene-9,10-dione (5a) and 2,3-(dibutylamino)anthracene-9,10-dione (5b). All amino-anthraquinones were produced via nucleophilic substitution mechanisms. Aminoanthraquinones 3a, 5a and $\mathbf{5 b}$ were found to demonstrate strong cytotoxic activity against both MCF-7 (IC $\mathrm{I}_{50}$ 1.1, 1.1 and $3.0 \mu \mathrm{g} / \mathrm{mL}$ respectively) and Hep-G2 cancer cell lines ( $\mathrm{IC}_{50} 1.2,3.0$ and $13.0 \mu \mathrm{g} / \mathrm{mL}$, respectively).

\section{Acknowledgments}

We are grateful to FRGS (Vot. No. 5523918) and RUGS (Vot. No. 9342700) for financial support, Department of Chemistry, Faculty of Science, UPM for the research facilities, Zainal for MS spectra and Rusnani for the IR spectra. 


\section{Conflict of Interest}

The authors declare no conflict of interest.

\section{References}

1. Ashnagar, A.; Bruce, M.; Dutton, L.; Prince, R.C. One- and two-electron reduction of hydroxy1,4-naphthoquinones and hydroxy-9,10-anthraquinones: The role of internal hydrogen bonding and its bearing on the redox chemistry of the anthracycline antitumour quinones. BBA-Gen Subjects 1984, 801, 351-359.

2. Ge, P.; Russel, R.A. The synthesis of anthraquinone derivatives as potential anticancer agent. Tetrahedron 1997, 53, 17469-17476.

3. Hua, D.H.; Lou, K.; Havens, J.; Perchellet, E.M.; Wang, Y.; Perchellet, J.P.; Iwamotoc, T. Synthesis and in vitro antitumor activity of substituted anthracene-1,4-diones. Tetrahedron 2004, 60, 10155-10163.

4. Chang, P.; Chen, C. Isolation and characterisation of antitumour anthraquinones from Morinda umbellata. Chin. Pharm. J. (Taipei) 1995, 47, 347-353.

5. Yadav, J.P.; Arya, V.; Yadav, S.; Panghal, M.; Kumar, S.; Dhankhar, S. Cassia occidentalis L.: A review on its ethnobotany, phytochemical and pharmacological profile. Fitoterapia 2010, 81, 223-230.

6. Osman, C.P.; Ismail, N.H.; Ahmad, R.; Ahmat, N.; Awang, K.; Jaafar, F.M. Anthraquinones with antiplasmodial activity from the roots of Rennellia elliptica Korth. (Rubiaceae). Molecules 2010 , $15,7218-7226$.

7. Sittie, A.A.; Lemmich, E.; Olsen, C.E.; Hviid, L.; Kharazmi, A.; Nkrumah, F.K.; Christensen, S.B. Structure-Activity studies: In vitro antileishmanial and antimalarial activities of anthranones from Morinda lucida. Planta Med. 1999, 65, 259-261.

8. Xiang, W.; Song, Q.S.; Zhang, H.J.; Guo, S.P. Antimicrobial anthraquinones from Morinda angustifolia. Fitoterapia 2008, 79, 501-504.

9. Rath, G.; Ndonzao, M.; Hostettmann, K. Antifungal anthraquinones from Morinda lucida. Int. J. Pharmacogn. 1995, 33, 107-114.

10. Chang, P.; Lee, K.H. Cytotoxic antileukemic anthraquinones from Morinda parvifolia. Phytochemistry 1984, 23, 1733-1736.

11. Ismail, N.H.; Ali, A.M.; Aimi, N.; Kitajima, M.; Takayama, H.; Lajis, N.H. Anthraquinone from Morinda ellintica. Phytochem. 1997, 45, 1723-1725.

12. Schinazi, R.F.; Chu, C.K.; Babu, J.R.; Oswald, B.J.; Saalmann, V.; Cannon, D.L.; Eriksson, B.F. H.; Nasr, M. Anthraquinones as a new class of antiviral agents against human immunodeficiency virus. Antiviral Res. 1990, 13, 265-272.

13. Alves, D.S.; Pérez-Fons, L.; Estepa, A.; Micol, V. Membrane-related effects underlying the biological activity of the anthraquinones emodin and barbaloin. Biochem. Pharmacol. 2004, 68, 549-561. 
14. Andersen, D.O.; weber, N.D.; Wood, S.G.; Hughes, B.G.; Murray, B.K.; North, J.A. In vitro virucidal activity of selected anthraquinones and anthraquinones derivatives. Antiviral Res. 1991, 16, 185-196.

15. Barnard, D.L.; Huffman, J.H.; Morris, J.L.; Wood, S.G.; Hughes, B.G.; Sidwell, R.W. Evaluation of the antiviral activity of anthraquinones, anthrones and anthraquinones derivatives against human cytomegalovirus. Antiviral Res. 1992, 17, 63-77.

16. Yen, G.C.; Duh, P.D.; Chuang, D.Y. Antioxidant activity of anthraquinones and anthrones. Food Chem. 2000, 70, 437-441.

17. Sokolyuk, N.T.; V.V. Romanov, L.P.; Pisulina, L.P. Naphthacenequinones: Synthesis and properties. Russ. Chem. Rev. 1993, 62, 1005-1024.

18. Bechtold, T.; Burtscher, E.; Turcanu, A. Anthraquinones as mediators for the indirect cathodic reduction of dispersed organic dyestuffs. J. Electroanal Chem. 1999, 465, 80-87.

19. Guo, J.; Zhou, J.; Wang, D.; Tian, C.; Wang, P.; Salah Uddin, M.; Yu, H. Biocatalyst effects of immobilised anthraquinone on the anaerobic reduction of azo dyes by the salt-tolerant bacteria. Water Res. 2007, 41, 426-432.

20. Ahn, K.D.; Yoo, K.W.; Soh, J.H.; Kang, J.H. Fluorescent photoimaging with polymers having protected quinizarin dye precursors by a dry process based on chemical amplification. React. Funct. Polym. 2009, 69, 111-116.

21. Shchekotikhin, A.E.; Glazunova, V.A.; Dezhenkova, L.G.; Shevtsova, E.K.; Traven, V.F.; Balzarini, J.; Huang, H.S.; Shtil, A.A.; Preobrazhenskaya. M.N. The first series of 4,11-bis[(2-aminoethyl)amino]anthra[2,3-b]furan-5,10-diones: Synthesis and anti-proliferative characteristics. Eur. J. Med. Chem. 2011, 46, 423-428.

22. Lee, C.C.; Huang, K.F.; Lin, P.Y.; Huang, F.C.; Chen, C.L.; Chen, T.C.; Guh, J.H.; Lin, J.J.; Huang, H.S. Synthesis, antiproliferative activities and telomerase inhibition evaluation of novel asymmetrical 1,2-disubstituted amidoanthraquinone derivatives. Eur. J. Med. Chem. 2012, 47, 323-336.

23. Jin, G.Z.; Song, G.Y.; Zheng, X.G.; Kim, Y.; Sok, D.E.; Ahn, B.Z. 2-(1 -Oxyalkyl)-1,4-dioxy9,10-anthraquinones: Synthesis and evaluation of antitumor activity. Arch. Pharm. Res. 1998, 21, 198-206.

24. Teich, L.; Daub, K.S.; Krugel, V.; Nissler, L.; Gebhardt, R.; and Eger, K. Synthesis and biological evaluation of new derivatives of emodin. Bioorg. Med. Chem. 2004, 12, 5961-5971.

25. Shchekotikhin, A.E.; Glazunova, V.A.; Luzikov, Y.N.; Buyanov, V.N.; Susova, O.Y.; Shtil, A.A.; Preobrazhenskaya, M.N. Synthesis and structure-activity relationship studies of 4,11diaminophtho[2,3-f]indole-5,10-diones. Bioorg. Med. Chem. 2006, 14, 5241-5251.

26. Shchekotikhin, A.E.; Shtil, A.A.; Luzikov, Y.N.; Bobrysheva, T.V.; Buyanov, V.N.; Preobrazhenskaya, M.N. 3-Aminomethyl derivatives of 4,11-dihydroxynaphtho[2,3-f]indole-5,10dione for circumvention of anticancer drug resistance. Bioorg. Med. Chem. 2005, 13, 2285-2291.

27. Krapcho, A.P.; Shaw, K.J.; Landi, J.J., Jr.; Phinney, D.J. Synthesis of unsymmetrical 1,4-Bis[(aminoalkyl)amino]anthracene-9,10-diones for Antineoplastic Evaluation. J. Org. Chem. 1984, 49, 5253-5255. 
28. Glänzel, M.; Bültmann, R.; Starke, K.; Frahm, A.W. Structure-activity relationships of novel P2-receptor antagonists structurally related to reactive blue 2. Eur. J. Med. Chem. 2005, 40, 1262-1276.

29. Baqi, Y.; Müller, C.E. Efficient and mild deamination procedure for 1-Aminoanthraquinones yielding a diverse library of novel derivatives with potential biological activity. Tetrahedron Lett. 2012, 53, 6739-6742.

30. Jin, G.Z.; Jin, H.S.; Jin, L.L. Synthesis and antiproliferative activity of 1,4-Bis(dimethylamino)9,10-anthraquinone derivatives against P388 mouse leukemic tumor cells. Arch Pharm. Res. 2011, 34, 1071-1076.

31. Sugimoto, N.; Kawasaki, Y.; Sato, K.; Aoki, H.; Ichi, T.; Koda, T.; Yamazaki, T.; Maitani, T. Structure of Acid-Stable Carmine. J. Food Hyg. Soc. Jpn. 2002, 43, 18-23.

32. Zielske, A.G. (Tosyloxy)anthraquinones: Versatile synthones for the preparation of various aminoanthraquinones. J. Org. Chem. 1987, 52, 1305-1309.

33. Camara, C.A.; Pinto, A.C.; Rosa, M.A.; Vargas, M.D. Secondary amine and unexpected 1-Aza-anthraquinone from 2-Methoxylapachol. Tetrahedron 2001, 57, 9569-9574.

34. Saha, K.; Lam, K.W.; Abas, F.; Hamzah, A.S.; Stanslas, J.; Hui, L.S.; Lajis, N.H. Synthesis of damnacanthal, a naturally occurring 9,10-Anthraquinone and its analogues, and its biological evaluation against five cancer cell lines. Med. Chem. Res. 2013, 22, 2093-2104.

35. Sukari, M.A.; Tang, S.W.; Neoh, B.K.; Ee, G.C.L.; Rahmani, M. Antileukemic activity and chemical constituents of some Zingiberaceae species. Asian J. Chem. 2010, 22, 7891-7896.

36. Garba, S.; Okenyi, S.O. Antimicrobial activities of total alkaloids extracted from some nigerian medicinal plants. J. Microbiol. Antimicrob. 2012, 4, 60-63.

Sample Availability: Samples of the compounds $\mathbf{3 a}$ and $\mathbf{5 d}$ are available from the authors.

(C) 2013 by the authors; license MDPI, Basel, Switzerland. This article is an open access article distributed under the terms and conditions of the Creative Commons Attribution license (http://creativecommons.org/licenses/by/3.0/). 